\title{
Penegakan Hukum Cyber Crime Terhadap Tindak Pidana Pencurian Uang Nasabah Dengan Cara Pembajakan Akun Internet Banking Lewat Media Sosial
}

\author{
Ryan Aditama \\ Fakultas Hukum Universitas Batanghari \\ Jalan Slamet Riyadi Broni Kota Jambi Telp: (0741) 65351 \\ Correspondence email: ryan.aditama@unbari.ac.id
}

\begin{abstract}
Abstrak. Kejahatan di bidang dunia maya atau biasa dikenal dengan kata disebut dengan cyber crime pada dasarnya mengarah kepada perangkat komputer serta alat-alat teknologi yang menggunakan sistem yang terhubung dengan internet sebagai unsur penggunaannya. Kemajuan pada bidang teknologi informasi yang menjadi asal muasal dari munculnya cyber crime ini, secara yuridis akan membawa dampak baik positif maupun negatifnya kepada hukum itu sendiri. Disisi lain para pelaku kejahatan, khususnya para hacker yang dengan sengaja melakukan perbuatan secara illegal untuk mengambil data pribadi sesorang, khususnya bagai para pengguna Internet Banking yang terhubung dengan nomor whatsapp milik akun banknya, tentunya telah banyak para pelaku kejahatan yang menggunakan kesempatan itu untuk membobol akun Internet Banking milik seseorang, belakangan ini sering terjadi dengan alasan pihak operator meminta kode OTP (One-Time-Paswrord). Terkait dengan penelitian yang dibuat oleh penulis ini dengan penggunaan tipe penelitian yang bersifat yuridis normatif disini terkait pada penelitian yang ditujukan kepada aturan norma yang termuat pada suatu aturan perundangan, sedangkan konsep pendekatan yang digunakan merupakan pendekatan dari perundangan serta pendekatan konsep melalui mengungkapan beberapa asas-asas hukum yang berkaitan dengan Penegakan Hukum Cyber Crime Terhadap Tindak Pidana Pencurian Uang Nasabah Dengan Cara Pembajakan Akun Internet Banking Lewat Media Sosial, pembahasan dilakukan dengan cara deduktif untuk memperoleh kesimpulan yang bersifat kualitatif. Terkait dengan kejahatan cyber crime terhadap tindak pidana pencurian uang nasabah dengan cara pembajakan akun internet banking lewat media sosial menjadi persoalan yang sangat urgent untuk di tindak lanjuti, karena di era modern saat ini, segala kegiatan manusia tidak dapat di pisahkan serta dijauhkan dari Internet serta penggunana akun Internet Banking, dimana segala sesuatunya pada saat ini dituntu untuk menjadi modern akibat perkembangan bidang teknologi dan informasi yang sangat pesat saat ini dan juga merupakan hal yang harus segera diselesaikan. Pemerintah indonesia dalam hal ini merupakan bagian dari Kementerian Informasi dan Komunikasi yang bekerja dengan seluruh stakeholders dan berupaya untuk mewujudkan asa itu.
\end{abstract}

Kata Kunci: Penegakan Hukum; Cyber Crime; Pencurian Uang Nasabah

Abstract. Crime in the field of cyberspace or commonly known as cyber crime basically refers to computer devices and technological devices that use a system connected to the internet as an element of its use. Progress in the field of information technology, which is the origin of the emergence of cyber crime, will legally bring both positive and negative impacts to the law itself. On the other hand, criminals, especially hackers who deliberately commit acts illegally to take someone's personal data, especially like Internet Banking users who are connected to the whatsapp number belonging to their bank account, of course many criminals have used this opportunity to break into the account. Someone's Internet Banking lately often happens because the operator asks for an OTP (One-Time-Passwrord) code. Related to the research made by this writer with the use of the type of research that is normative juridical here is related to research aimed at the rules of norms contained in a rule of law, while the conceptual approach used is an approach of legislation and a conceptual approach through disclosing several principles Laws relating to Law Enforcement of Cyber Crime Against Crime of Theft of Customer Money By Hijacking Internet Banking Accounts Through Social Media, discussions are conducted in a deductive manner to obtain qualitative conclusions. Related to the crime of cyber crime against the crime of theft of customer money by hijacking internet banking accounts via social media is a very urgent issue to be followed up, because in today's modern era, all human activities cannot be separated and kept away from the Internet and its users. Internet Banking account, where everything is currently being demanded to be modern due to the rapid development of technology and information at this time and is also something that must be resolved immediately. The Indonesian government in this case is part of the Ministry of Information and Communication which works with all stakeholders and strives to realize this hope.

Keywords: Law Enforcement; Cyber Crime; Theft of Customer Money

\section{PENDAHULUAN}

Sejalan dengan perkembangan zaman serta terhadap pembangunan yang semakin meningkat yang tidak terlepas juga pada segala aspek yang berhubungan dengan kehidupan manusia. Terkait pada perkembangan di dalam hidup masyarakat atas segala permasalahan yang ada, yang semakin mudah terkait dengan penyelesaian permasalahanya ataupun sebaliknya ada juga sebagian kecil masyarakat yang mengalami kesulitan terkait dengan menghadapi serta untuk mencukupi kebutuhan hidupnya. Hal ini mengakibatkan turut berkembang pesatnya teknologi yang berkembang dalam masyarakat. Perkembangan dalam tingkat teknologi ini jugalah, yang akan berpengaruh terkait dengan dampak 
yang terjadi pada hampir semua aspek kehidupan manusia, dan juga akan mengubah perilaku masyarakat, serta peradaban manusia secara menyeluruh, disisi laian, perkembangan terkait di bidang teknologi telah mengakibatkan terkait dengan kehidupan dunia menjadi tanpa batas. ${ }^{1}$ Terhadap dengan kemajuan teknologi yang semakin pesat, tentunya akan menimbulkan suatu dampak dari segi yang bersifat positif ataupun yang bersifat negatif. Namun sejalan dengan perkembangan zaman, atas pemanfaatan teknologi informasi yang telah mengubah baik dalam segi perihal perilaku masyarakat ataupun yang berkaitan dengan peradaban manusia secara luas. Perkembangan teknologi informasi serta komunikasi y ang telah pula menciptakan hubungan dunia menjadi tidak ada batasan (borderless) dan mengakibatkan perubahan sosial, ekonomi, serta budaya secara signifikan akan berljalan dengan cepat. ${ }^{2}$

Perkembangan atas teknologi serta sistem informasi yang tidak menutup kemungkinan akan adanya seseorang yang akan melakukan tindakan kejahatan. Pada zaman ini, banyak sekali bentuk kejahatan baru yang lahir muncul disebabkan penyalahgunaan atas perkembangan teknologi dan sistem informasi. Pada dasarnya, kejahatan di bidang teknologi maupun di bidang komputer ataupun mengenai alat yang telah diotomatisasikan, yang termasuk kedalam kejahatan yang biasa, namun dilakukan dengan menggunakan peralatan yang canggih.

Kejahatan dibidang dunia maya ini, mengarah kepada aktifitas kejahatan dengan cara sistem kerja komputer atau jaringan sebuah perangkat komputer menjadi alat utamanya, tujuannya atau tempat akan terjadinya kejahatan. Perihal ini, merupakan bagian dari kejahatan dunia maya yang antara lain lelang secara online, pemalsuan cek, penipuan kartu kredit, pencurian data nasabah secara illegal, penipuan terhadap data identitas seseorang maupun pornografi anak. ${ }^{3}$ Berkembangannya teknologi serta penerapan ini telah memasuki dan berpengaruh dengan kuat dalam kehidupan modern saat ini, hingga sebagian besar dari sebuah kegiatan bisnis ini telah mempercayakan pada teknologi yang modern itu, salah satunya adalah industri dibidang perbankan.

Pada zaman modern ini sudah muncul dengan apa yang dinamakan dengan rezim hukum baru yang disebut dengan hukum cyber. Mengenai kata hukum cyber diartikan kepada padanan kata yang berasal dari cyber law, yang pada saat ini secara internasional dipergunakan sebuah istilah hukum yang terkait dengan pemanfaatan teknologi informasi tersebut. ${ }^{3}$ Kejahatan di bidang dunia maya atau biasa dikenal dengan kata disebut dengan cyber crime pada dasarnya mengarah kepada perangkat komputer serta alat-alat teknologi yang menggunakan sistem yang terhubung dengan internet sebagai unsur penggunaannya. Kemajuan pada bidang teknologi informasi yang menjadi asal muasal dari munculnya cyber crime ini, secara yuridis akan membawa dampak baik positif maupun negatifnya kepada hukum itu sendiri.. Kepada tindakan cyber crime, dikarenakan dampak dari munculnya perbuatan cyber crime ini, akan menimbulkan sifat negatif yang akan merusak terkait dengan bidang kehidupan modern pada saat ini, oleh karena itu kemajuan di bidang teknologi komputer ini akan menjadi salah satu pendukung bagi kehidupan di dalam masyarakat tentunya. Perkembangan di bidang teknologi serta penerapannya ini akan masuk dan mempengaruhi dengan kuat pada bidang kehidupan modern saat ini, bahkan sebagian besar pada kegiatan bisnis akan mempergunakan sistem teknologi tersebut.

Penggunaan jaringan internet ini telah menciptakan sebuah realitas kehidupan baru dari segi peradaban manusia modern saat ini. Internet telah membuat akan jarak serta waktu menjadi tidak ada batasannya lagi. Dengan penggunaan medium internet orang bisa melakukan berbagai macam tingkat aktivitas dimana pada kehidupan nyata akan sulit dikerjakan, dikarenakan perbedaan jarak maupun waktu. Suatu kenyataan dimana pada jarak berkilo-kilo meter dari tempat kita berada dengan orang yang berada di tempat yang jauh, dengan penggunaan medium internet akan dapat memunculkan orang tersebut di hadapan kita. Ketika sebuah penggunaan dari teknologi internet yang semakin berkembang dengan pesat maka media sosial juga akan memberi dampak akan pembangunan dengan pesat.

Pada zaman modern saat ini, manusia tidak terlepas dengan penggunaan media sosial. Media sosial merupakan sejenis media yang dipergunakan untuk media yang bersifat bebas untuk mengekspresikan serta mengeplor pendapat yang kita miliki secara terus-menerus. Disisi lain, jaringan sosial merupakan laman di mana seseorang akan membuat sebuah laman web (akun media sosialnya) secara pribadi, dan akan terhubung serta dapat berkomunikasi dengan orang-orang yang dikenalnya maupun orang baru yang di kenalnya di dunia maya. Jaringan sosial yang sering dipergunkan oleh masyrakat diantaranya Whatsapp, Telegram, Facebook, Twitter, dan lain sebagainya.

Disisi lain para pelaku kejahatan, khususnya para hacker yang dengan sengaja melakukan perbuatan secara illegal untuk mengambil data pribadi sesorang, khususnya bagai para pengguna Internet Banking yang terhubung dengan nomor whatsapp milik akun banknya, tentunya telah banyak para pelaku kejahatan yang menggunakan kesempatan itu untuk membobol akun Internet Banking milik seseorang, belakangan ini sering terjadi dengan alasan pihak operator meminta kode OTP (One-Time-Paswrord), seperti kasus yang terjadi, berdasarkan temuan polisi, sejak 2017 hingga tertangkap di tahun 2020, para tersangka telah mengambilalih sebanyak 3.070 rekening dengan total

${ }^{1}$ Ahmad M. Ramli, Tinjauan Cyber Law serts terkait dengan Haki, Sinar Grafika, Bandung, 2008. Hlm. 2.

${ }^{2}$ Barda Nawawi Arief. Penanggulangan Terhadap Tindak Pidana Pada Kejahatan DiBidang Telematika Dan Informatika, Budi Utama, Jakarta, 2010, Hlm. 85.

${ }^{3}$ Ahmad M. Ramli, Op, Cit, Hlm. 5. 
kerugian yang dialami korban sebesar 21 miliar. $^{4}$

Ini menjadi persoalan yang sangat besar untuk diatasi. Para pengguna Internet khususnya yang mempunyai akun Internet Banking yang terhubung dengan akun media sosialnya akan rentang untuk di retas datanya untuk di ambil oleh Hacker. Hal inilah yang kemudian untuk dijadikan persoalan mengapa harus belajar untuk menggunakan internet dengan baik dan benar, agar tidak terjadi pembobolan rekening nasabah oleh orang yang tidak dapat bertanggungjawab. Hal ini diperlukan untuk mencegah penggunaan efek samping dari penggunaan media sosial yang tidak terduga dan yang tidak diinginkan. Masalah utamanya adalah kejahatan dalam masyarakat terkait dengan penggunaan akun media sosial. Hal inilah yang harus diperhatikan oleh pemerintah dengan penggunaan infrastruktur hukum serta pengaturannya sehingga penggunaan sebuah teknologi informasi yang digunakan secara aman untuk mencegah penyalahgunan.

Sebagaimana yang termuat dalam Undang-Undang ITE No 11 Tahun 2008, dalam Pasal :

a. Pasal 31 ayat 1: Setiap orang dengan sengaja dan tanpa hak atau melawan hukum melakukan intersepsi atau penyadapan atas informasi elektronika dan atau dokumen elektronik dalam suatu komputer dan atau sistem elektronik secara tertentu milik orang lain.

b. Pasal 31 ayat 2: Setiap orang dengan sengaja atau tanpa hak atau melawan hukum melakukan intersepsi atau transmisi elktronik dan atau dokumen elektronik yang tidak bersifat publikdari, ke, dan di dalam suatu komputer dan atau sistem elektronik tertentu milik orang lain, baik yang tidak menyebabkan perubahan, penghilangan dan atau penghentian informasi elektronik dan atau dokumen elektronik yang ditransmisikan.

c. Pasal 47 : Setiap Orang yang memenuhi unsur sebagaimana dimaksud dalam Pasal 31 ayat (1) atau ayat (2) dipidana dengan pidana penjara paling lama 10 (sepuluh) tahun dan/atau denda paling banyak Rp800.000.000,00 (delapan ratus juta rupiah).

Ada banyak modus dan motif yang dilakukan oleh pelaku dengan tujuan untuk mengambil keuntungan. Salah satunya dengan membajak akun WhatsApp seseorang, lalu memanfaatkan data pribadi atau akun digitalnya. Perbuatan seperti ini dikenal dengan nama scam, dimana perbuatan tersebut merupakan kejahatan yang dilakukan oleh pelaku menipu calon korban dengan modus untuk memberikan kode angka atau informasi terkait data diri dari pribadi orang tersebut, sehingga pelaku bisa mengakses akun pribadi milik calon korban.

Pada kenyataannya, para pelaku pembobol uang milik nasabah sulit untuk di ungkap, karena sulit untuk mencari lokasi dimana para hecker bersembunyi, dan mereka melakukan aksinya dengan menggunakan media Internet, tentunya ini menyulitkan bagi pihak kepolisian untuk mengungkapnya.

\section{Rumusan Masalah}

Rumusan masalah terkait dengan penulisan jurnal ini adalah : Bagaimana penegakan hukum Cyber Crime untuk mengatasi tindak pidana pencurian Uang Nasabah Dengan Cara Pembajakan Akun Internet Banking Lewat Media Sosial ?

\section{METODE}

Terkait dengan penelitian yang dibuat oleh penulis ini dengan penggunaan tipe penelitian yang bersifat yuridis normatif disini terkait pada penelitian yang ditujukan kepada aturan norma yang termuat pada suatu aturan perundangan, sedangkan konsep pendekatan yang digunakan merupakan pendekatan dari perundangan serta pendekatan konsep melalui mengungkapan beberapa asas-asas hukum yang berkaitan dengan Penegakan Hukum Cyber Crime Terhadap Tindak Pidana Pencurian Uang Nasabah Dengan Cara Pembajakan Akun Internet Banking Lewat Media Sosial, pembahasan dilakukan dengan cara deduktif untuk memperoleh kesimpulan yang bersifat kualitatif.

\section{HASIL DAN PEMBAHASAN}

\section{Penegakan Hukum Cyber Crime Terhadap Tindak Pidana Pencurian Uang Nasabah Dengan Cara Pembajakan Akun Internet Banking Lewat Media Sosial}

Perlunya perlindungan hukum terkait dengan kegiatan yang dilakukan di internet, baik pengunaan akun media sosial, Internet Banking maupun kegiatan yang berbentuk bisnis dengan penggunaan jaringan yang terhubung dengan Internet. Dengan menggunakan pengembangan terkait dengan perlindungan baik secara teknis dengan cara penggunaan berbagai sistem yang diciptakan oleh para ahli bidang komputer dan network diharapkan agar korban dari kejahatan yang diakibatkan cyber crime ini dapat diminimalisir ataupun dapat di cegah secara konsisten, selain dengan adanya implementasi terkait dengan penegakan hukum (law enforcement) yang konsisten dan benar-benar ditujukan

${ }^{4}$ Sumberhttps://nasional.kompas.com/read/2020/10/05/18440581/bareskrim-tangkap-10-tersangka-kasus-dugaanpengambilalihan-rekening-lewat di akses pada tanggal 25 maret 2021 pukul $21.00 \mathrm{Wib}$. 
untuk memerangi cyber crime. ${ }^{5}$

Hal ini tentunya tidak terlepas juga dari peran pihak Bank yang dapat membantu memerangi kejahatan cyber crime terkait dengan pencurian uang milik nasabah secara illegal. Di Indonesia sendiri sudah mempunyai aturan hukum terkait dengan tindak pidana cyber crime ini yang menjadi permasalahan disini adalah, semakin pesat perkembangan teknologi dengan penggunaan Internet ini, para pelaku kejahatan selalu menggunakan cara yang baru dengan berbagai motif yang ada, tanpa diketahui oleh pihak Bank maupun aparat penegak hukum.

Untuk mencegah perkembangan teknologi yang sangat cepat, maka dari segi keamanan penggunaan Internet Banking itu sendiri, sudah seharusnya di tingkatkan keamanannya, karena resiko yang muncul akibat penyalahgunaan data pribadi milik nasabah yang di ambil secara illegal akan berdampak hilangnya uang nasabah bahkan tanpa di sadari oleh pihak nasabah itu sendiri.

\section{Kebijakan Dalam Hukum Pidana Terkait Penegakan Hukum Cyber Crime Terhadap Tindak Pidana Pencurian Uang Nasabah Dengan Cara Pembajakan Akun Internet Banking Lewat Media Sosial Penanggulangan Kejahatan Cyber Crime Melalui Kebijakan Hukum Pidana}

Seperti yang kita ketahui, untuk menentukan perbuatan itu dapat tergolong sbegai tindak pidana atau bukan, maka harus dilihat dulu unsur-unsur dari tindak pidana itu sendiri, harus jelas bahwa perbuatan itu termasuk atau tidak kedalam perbuatan pidana. Tidak mudah untuk menyatakan bahwa suatu perbuatan itu sebagai suatu tindak pidana artinya terkait dengan pernyataan tersebut harus ada beberapa proses yang harus dilakukan. Selain dengan menggunakan kajian yang secara mendalam terkait dengan perbuatan tersebut, maka dari segi kriminologi, harus ada sebuah cara dengan mempertimbangkan pula beberapa hal yang harus diperhatikan terkait dengan perbuatan tersebut, yaitu dengan melihat apa yang menjadi tujuan dari hukum pidana itu sendiri, terkait dengan penetapan sebuah perbuatan yang tidak ingin dikehendaki, perbandingan terkait dengan sarana serta hasil maupun kemampuan dari segi penegak hukum. Terkait dengan hal tersebut, maka diperlukan sebuah kajian dalam hal pertimbangan terkait dengan strategi yang mendalam untuk mengkualifikasikan terkait dengan kriminalisasi tersebut hal ini merupakan bagian dari kebijakan atau politik kriminal. ${ }^{6}$

Kebijakan atau penanggulangan dari sebuah tindak pdana kejahatan pada dasarnya merupakan bagian yang sangat berhubungan dengan integral perihal upaya untuk melakukan perlindungan bagi masyarakat (social defence) serta upaya untuk mencapai kesejahteraan apa yang menjadi kebahagian bagi masyarakat itu sendiri (social welfare). Secara umum, disebutkan bahwa apa yang menjadi tujuan akhir maupun yang menjadi tujuan utama dari sebuah politik kriminal adalah perlindungan terkait dengan masyarakat serta yang menjadi tujuan utamanya adalah mencapai kesejahteraan masyarakat. Terkait dengan penanggulangan kejahatan dengan menggunakan hukum pidana itu sendiri pada dasarnya juga merupakan bagian dari usaha terkait dengan penegakan hukum (terutama terkait dengan penegakan hukum pidana).

\section{Penaggulangan Cyber Crime dengan Hukum Pidana}

Pada dasarnya sebuah kebijakan dari segi legislatif maupun kebijakan terkait dengan perundang-undangan, secara fungsional akan dapat dipandang sebagai bagian dari sebuah perencanaan maupun mekanisme tersendiri terkait dengan penanggulangan kejahatan, maka dapat dikatakan bahwa sebagai bagian dari langkah awal untuk mengatasi masalah tersebut. Kebijakan ataupun apa yang dikatakan dengan upaya penanggulangan dari sebuah tindakan yang tergolong kedalam sebuah kejahatan pada hakikatnya itu sendiri merupakan bagian yang integral yang terkait dengan upaya perlindungan masyarakat (social defence) serta dengan upaya mencapai apa yang dinamakan dengan kesejahteraan masyarakat ( social welfare). ${ }^{7}$

Terhadap teori-teori kebijakan hukum pidana di atas, terkait dengan penggunaan hukum pidana yang pada prinsipnya merupakan kegiatan upaya pencegahan serta bagaimana melakukan penanggulangan cybercryme yang sangat relevan dan perlu diingat mengenai bahaya yang ditimbulkan serta kerugian yang akan ditimbulkan terhadap meningkat pesatnya sebuah kejahatan dari tindak pidana di bidang teknologi dan informasi informasi tersebut, hal ini tentuanya akan menjadi pertimbangan yang sangat layak untuk di pertimbangkan.

Perbuatan ini merupakan perbuatan yang berbeda dengan kejahatan konvensional pada umumnya yang dampaknya relatif dangat muda diselesaikan, terhdap maksimum kerugiaan yang ditimbulkan sebesar nilai yang akan melekat pada sasaran kejahatan itu sendiri, terhadap kejahatan cyber dimana keterkaitan antara pelaku maupun korbannya tidak harus berada pada posisi ruang yang berdekatan ataupun waktu yang sama hal ini mengingat, bahwa kejahatan pengambilan uang milik nasabah secara illegal ini dilakukan di dunia maya dengan pola sistem yang

${ }^{5}$ Budi Suhariyanto, Tindak Pidana Dari Kejahatan Di Bodang Teknologi Informas, Rajawali Pers Nusantara , Jakarta, 2011, hlm. 23.

${ }^{6}$ Ibid, Hal. 29.

${ }^{7}$ Ibid, Hal. 42. 
terhubung dengan sistem Internet, dengan cara para pelaku kejahatan membobol sistem Internet Banking milik nasabah tersebut secara halus dengan meminta kode OTP ataupun dengan cara tertutup artinya, si pemilik akun Internet Banking secara langsung tidak sadar bahwa uang miliknya telah berkurang maupun hilang sepenuhnya. Hal ini mengakibatkan, sehingga sulit untuk mencari siapa pelakunya maupun keberadaan dari pelaku tersebut serta nominal nilai kerugian yang akan ditimbulkan akibat kejahatan pembobolan uang milik nasabah ini menjadi tidak terbatas pada nilai materiil yang melekat pada sasaran yang telah di tujunya. Maksudnya disini bahwa, nilai kerugian yang dialami seorang akun nasabah tersebut sering kali jauh lebih besar ataupun hingga pada nominal yang tak ternilai harganya. Terkait dengan permasalahan seperti ini, maka diperlukan upaya penanggulangan terhadap kejahatan teknologi informasi seperti ini baik upaya pencegahan kejahatan secara preventif serta penanggulangan kejahatan dengan cara yang bersifat represif.

Salah satu upaya untuk melakukan penanggulangan kejahatan tersebut adalah melalui saran media hukum pidana. Dimana hukum pidana dipanggil untuk menyelamatkan atas kerugian yang diderita oleh masyarakat yang menjadi korban dari pencurian uang milik nasabah tersebut, karena di zaman era modern seperti ini kejahatan tersebut akan berdampak negatif terhadap aktivitas kehidupan sosio-ekonomi masyarakat pada saat ini. Demikian pula terhadap aspek lain yang erat hubungannya terhadap dukungan untuk melakukan pembangunan bagi kesejahteraan masyarakat itu sendiri. Terkait hal itu maka sebagai bentuk dari perlindungan bagi kepentingan masyarakat (social defence), jelas peran dari hukum pidana iti sendiri sangat diperlukan agar dapat mengatasi kejahatan di bidang dunia cyber yang pada prinsipnya itu telah menjadi penghambat dari segi pembangunan kesejahteraan masyarakat (social welfare) di era modern saat ini. Upaya melalui jalur penerapan kebijakan hukum pidana yang integral yang harus dioptimalkan karena peran hukum pidana yang mempunyai sifat memaksa ini di harapkan agar para pelaku kejahatan pencurian uang milik nasabah menjadi takut, dan juga ini harus ada peran yang maksimal dari pihak kepolisian maupun pihak Bank. Hanya degan penggunaan penegakan hukum pidana yang terpadu dengan baiak dengan harapan fungsionalisasi hukum dalam hukum pidana dalam penangulangan cyber crime dapat terwujud.

\section{Masalah Terhadap Pertanggungjawaban Pidana Kejahatan Cyber Crime dalam kasus pencurian uang milik nasabah}

Mengenai pertanggungjawaban pidana dimana dalam hakikatnya mempunyai makna yaitu pencelaan kepada pembuat (subjek hukum) atas segala perbuatan pidana yang telah dilakukan oleh seseorang tersebut. Maka yang dimaksud dengan pertanggungjawaban pidana disini mengandung makna terdapat sebuah pencelaan yang bersifat objektif maupun pencelaan yang bersifat subjektif. Yang dimaksud dengan secara bersifat objektif disini dimana si pembuat sudah melakukan sebuah perbuatan pidana (dalam hal ini merupakan perbuatan yang dilarang/ serta melawan hukum dan akan dikenakan sanksi pidana yang dimana menurut hukum positif yang berlaku) serta yang dimaksud dengan secara yang bersifat subjektif disini dimana si pembuat akan dikenakan ataupun akan dipersalahkan kepadanya/ serta akan dikenakan pertanggungjawaban terhadap sebuah perbuatan pidana yang telah dilakukan olehnya sehinga atas perbuatan tersebut ia akan dikenakan sanksi pidana.

Melihat dari pengertian diatas, sehingga dalam arti luas, persyaratan untuk di minta atas pertanggungjawaban pidana kepadanya pada kenyataannya identik dengan sebuah persyaratan perihal dalam pemidanaan (penjatuhan terhadap pidana/ tindakan). Hal ini berarti, terhadap asas-asas dalam pertanggungjawaban pidana juga akan identik terhadap asas-asas dalam pemidanaan ini pada umumnya, merupakan sebuah asas legalitas maupun asas culpabilitas. Dengan demikian dapat dikatakan bahwa sebuah sistem pertanggungjawaban pidana itu sendiri dalam arti yang luas dapat dinyatakan tidak dapat dipisahkan terhadap keseluruhan dari sitem mengenai pemidanaan itu sendiri.

Persyaratan serta asas-asas dalam pertanggungjawaban pidana itu sendiri yang dikemukakan sebelumnya merupakan bagian dari hal-hal yang telah diterima baik secara umum maupun secara konvensional dimana dalam sebuah doktrin ataupun yang dapat dikatakan menjadi sebuah teori maupun yang terdapat didalam sebuah peraturan perundang-undangan. Maka yang menjadi permasalahan disini yaitu seberapa jauh sebuah doktrin ataupun teori serta ketentuan-ketentuan dalam hukum positif yang konvensial itu akan dapat juga digunakan terhadap apa yang menjadi masalah dalam pertanggungjawaban pidana dalam kejahatan cyber crime itu sendiri.

Kenyataannya terhadap aturan perundang-undangan yang ada pada saat ini masih ada keterbatasan dalam mengatasi permasalahan tersebut, hal ini berarti asas legalitas konvensional atau apa yang ada pada hukum positif saat ini telah menghadapi sebuah tantangan yang serius yang diakibatkan oleh perkembangan kejahatan cyber crime. Ini terjadi karena cyber crime itu sendiri merupakan:

1. Cyber crime berada pada tatanan lingkungan dimana elektronik serta dunia maya merupakan hal yang sulit untuk diidentifikasikan dengan pasti, sedangkan terhadap dalam asas legalitas konvensional dimana perbuatan tersebut bertitik bertolak dari sebuah perbuatan yang nyata serta dapat dinyatakan kepastian hukum.

2. Cyber crime itu sendiri berkaitan erat dengan sebuah perkembangan dari teknologi yang sangat canggih dimana yang sangat cepat dapat berubah sedangkan asas legalitas konvensional tersebut bertitik tolak pada sumber hukum 
formal ataupun dimakasud dengan hukum positif dimana hukum positif mengatur dan bersifat yang statis.

3. Cyber crime juga melampui serta mampu menembus batas-batas negara, sedangkan aturan-aturan yang diterapkan di suatu negara pada hakikatnya hanya dapat diberlakukan di dalam sebuah wilayah teritorialnya sendiri dalam hal ini bersifat nasional. ${ }^{8}$

Terhadap kondisi tersebut, harus ada sebuah tindakan maupun sebuah inovasi dari aparat penegak hukum untuk memaksimalkan sebuah peraturan yang ada dengan melakukan penafsiran ataupun konstruksi dalam bidang hukum yang secara tidak langsung bersumber pada teori dalam hal ini ilmu hukum, pendapat yang di doktrin oleh para ahli, maupun yurisprudensi, ataupun yang bersumber kepada ide-ide yang bersifat mendasar serta yang secara konseptual akan dapat dipertanggungjawabkan kedepannya.

Seperti apa yang telah dijelaskan di atas, terhadap pertanggungjawaban pidana ini juga akan mengandung makna terhadap pencelaan yang bersifat subjektif. Artinya, disini secara subjektif kepada si pembuat akan patut dicela ataupun dapat dipersalahkan maupun dipertanggungjawabkan kepadanya atas sebuah perbuatan pidana yang te la h dilakukan itu, sehingga ia akan dapat dijatuhkan dipidana. Secara mudah dapat dinyatakan terhadap kesalahan tersebut (dan hal ini dikenal dengan asas culpabilitas). Terhadap asas culpabilitas ini pun tentunya juga harus dilihat terhadap masalah dalam hal pertanggungjawaban kejahatan cyber crime, walaupun dalam hal menghadapi tantangan yang ada itu tersendiri terutama dalam kasus-kasus yang menyangkut kejahatan cyber crime dalam hal pencurian uang nasabah dengan penggunanan akses secara illegal akun milik nasabah, karena tidak mudah dalam hal pembuktian terkait dengan adanya sebuah unsur kesalahan (dolus/culpa) dalam permasalahan yang terjadi pada kejahatan cyber crime.

\section{Penegakan Hukum Terkait Dengan Kejahatan Cyber Crime Terhadap Tindak Pidana Pencurian Uang Nasabah Dengan Cara Pembajakan Akun Internet Banking Lewat Media Sosial}

Terkait dengan kejahatan cyber crime terhadap tindak pidana pencurian uang nasabah dengan cara pembajakan akun internet banking lewat media sosial menjadi persoalan yang sangat urgent untuk di tindak lanjuti, karena di era modern saat ini, segala kegiatan manusia tidak dapat di pisahkan serta dijauhkan dari Internet serta penggunana akun Internet Banking, dimana segala sesuatunya pada saat ini dituntu untuk menjadi modern akibat perkembangan bidang teknologi dan informasi yang sangat pesat saat ini dan juga merupakan hal yang harus segera diselesaikan. Pemerintah indonesia dalam hal ini merupakan bagian dari Kementerian Informasi dan Komunikasi yang bekerja dengan seluruh stakeholders dan berupaya untuk mewujudkan asa itu.

Komitmen dari pemeritah untuk menciptakan sebuah produk khusus terutama dibidang informasi dan transaksi pada bidang elektronik yang dapat dikatakan merupakan jawaban atas keprihatinan yang diakibatkan dari penegakan hukum dibidang telematika. Komitmen dalam hal ini juga sekaligus merupakan bagian dari wujud pertanggungjawaban secara moral oleh pemerintah terhadap kehidupan masyarakat yang juga untuk mewujudkan perwujudan tugas oleh negara serta melindugi warganegaranya dari kejahatan-kejahatan tersebut.

Pada hakikatnya terkait dengan pemanfaatan teknologi dan komunikasi telah mengubah kondisi baik dari segi perilaku yang ada pada kehidupan masyarakat ataupun terkait dengan peradaban manusia secara menyeluruh. Perkembangan teknologi informasi dan komunikasi ini juga mengakibatkan dampak pada hubungan dunia menjadi tanpa batas dan menjadi tidak berjarak serta menyebabkan perubahan pada tatanan sosial, ekonomi maupun budaya yang secara signifikan akan berlangsung dengan demikian cepat.

\section{Undang-Undang Yang Mengatur Tentang Informatika dan Transaksi Elektronik}

Lahirnya sebuah rezim hukum baru mengenai Informatika dan Transaksi Elektronik yang dikenal sebagai sebuah hukum telematika yang dapat dikatakan sebagai sebuah hukum yang bersifat respon positif. Hukum telematika atau biasa yang disebut dengan cyber law ini, secara internasional adalah untuk digunakan sebuah istilah dari hukum yang berkaitan atas pemanfaatan dari sebuah teknologi informasi serta di bidang komunikasi. Demikian pula terhadap bagian dari hukum telematika yang merupakan bagian dari perwujudan terhadap sebuah apa yang telah dinamakan dengan sebuah istilah yang dikenal dengan istilah konvergensi hukum dari telekomunikasi, hukum yang terkait dengan sebuah media, maupun yang dapat dikatan dengan sebuah hukum informatika. Ada juga terhadap sebuah istilah yang baru digunakan yaitu hukum teknologi dari informasi, hukum yang berasal dari dunia maya (virtual world of law), dan hukum yang bersifat mayantara. Istilah-istilah yang tersebut lahir mengingat adanya sebuah kegiatan yang telah dilakukan melalui sebuah jaringan sistem komputer maupun sistem komunikasi baik yang dilakukan dalam ruang lingkup lokal maupun yang berkaitan dengan ruang lingkup global (internet).

Sehubungan dengan hal tersebut, dunia hukum yang sebenarnya telah ada sejak lama memperluas dari sebuah

${ }^{8}$ Arif Nawawi barda, Kajian Mengenai Tindak Pidana Perbuatan Mayantara Terhadap Cyber Crime Di Indonesia, Sinar Grafika, Jakarta, 2015, Hal. 27. 
penafsiran terhadap asas maupun normanya ketika telah menghadapi sebuah persoalan atas kebendaan yang bersifat tidak berwujud, contohnya terhadap kasus pencurian energi listrik sebagai sebuah tindak pidana. Pada kenyataan di era modern saat ini kejahatan di bidangn Internet yaitu kegiatan siber tidak lagi merupakan bagian yang termasuk kedalam kategori sebuah kejahatan yang sederhana karena dalam praktiknya tidak lagi dibatasi oleh jangkauan batas dari sebuah wilayah dalam batasan suatu negara, yang akan mudah diakses hingga waktu kapanpun serta dimanapun berada. Kerugian yang dapat terjadi baik terhadap yang dilakukan pada pelaku transaksi maupun terhadap pada orang lain yang belum pernah melakukan transaksi sebelumnya, terhadap kasus yang heboh saat ini seperti pencurian uang milik nasabah yang tanpa diketahui oleh pemilik rekening tersebut. Di samping itu, mengenai masalah pembuktian dimana faktor ini merupakan bagian yang sangat penting, mengingat mengenai informasi dari elektronik ini bukan saja belum terakomodasi pada sistem hukum acara yang ada indonesia secara komprehensif, dan hal ini adalah bagian sangat rentan untuk diubah, serta disadap, maupun dipalsukan, serta dikirim ke berbagai penjuru dunia yang dalam ini waktunya bisa di tempuh dengan hitungan detik.

Pengaturan dalam kejahatan cyber crime terhadap tindak pidana pencurian uang nasabah secara Illegal ini ada terdapat dalam Undang-Undang ITE. Sebagaimana yang termuat dalam Undang-Undang ITE No 11 Tahun 2008, dalam Pasal :

a. Pasal 31 ayat 1: Setiap orang dengan sengaja dan tanpa hak atau melawan hukum melakukan intersepsi atau penyadapan atas informasi elektronika dan atau dokumen elektronik dalam suatu komputer dan atau sistem elektronik secara tertentu milik orang lain.

b. Pasal 31 ayat 2: Setiap orang dengan sengaja atau tanpa hak atau melawan hukum melakukan intersepsi atau transmisi elktronik dan atau dokumen elektronik yang tidak bersifat publikdari, ke, dan di dalam suatu komputer dan atau sistem elektronik tertentu milik orang lain, baik yang tidak menyebabkan perubahan, penghilangan dan atau penghentian informasi elektronik dan atau dokumen elektronik yang ditransmisikan.

c. Pasal 47 : Setiap Orang yang memenuhi unsur sebagaimana dimaksud dalam Pasal 31 ayat (1) atau ayat (2) dipidana dengan pidana penjara paling lama 10 (sepuluh) tahun dan/atau denda paling banyak Rp800.000.000,00 (delapan ratus juta rupiah).

Permasalahannya disini sulit untuk menentukan ataupun mencari siapa yang telah melakukan perbuatan kejahatan ini, karena kejahatan cyber crime ini dengan media Internet dan para pelaku kejahatan juga tidak diketahui keberadaanya, untuk itu aparat kepolisian diharapkan dengan cepat dan tegas, perihal pengungkapan kasus pencurian uang nasabah seperti ini. Di era modern saat ini, perkembangan dituntut ke arah dunia digital, tetapi apakah aparat kepolisian mampu untuk cepat tanggap terhadap permasalahan di dunia maya yang secara tidak langsung terus berkembang dengan berbagai macam motif yang mendasari pelaku dalam melakukan perbuatannya. Dampak yang akan muncul terhadap kejahatan dunia maya, akan mengakibatkan para nasabah semakin khawatir untuk melakukan kegiatan akses dengan transaksi penggunaan Internet Banking, sehingga pihak Bank akan semakin tidak dipercayai oleh masyarakat, karena tingkat keamanan yang sangat rendah. Sehingga pelatihan para aparat di bidang teknologi dan informasi harus selalu ditingkatan serta penerapan sanksi pidana yang diperberat dan harus ada interprestasi ataupun penafsiran, sehingga hukumnya menjadi tidak statis.

Menurut hemat penulis, untuk menghindari tindak kejahatan pencurian uang milik nasabah melalui Internet Banking, ada berapa cara yang dapat dilakukan oleh nasabah :

a. Para pengguna Handphone khususnya Android dan mempunyai akses yang terhubung dengan akun sosial media maupun adanya akaun Internet Banking yang melekat pada Handphone milik nasabah, agar selalu mengecek isi pesan yang masuk di Handphone, jika Anda merasa tidak pernah melakukan sesuatu hal-hal yang berhubungan ataupun melakukan kontak yang berhubungan dengan isi pesan yang dikirim tersebut, maka anda jangan mengikuti instruksi apapun terhadap apa yang anda dapatkan. Jika ada sebuah link yang terdapat dalam pesan itu, jangan anda mengkliknya atau menekan oke, karena jika anda mengkliknya maka dengan begitu akses terhadap data pribadi Anda bisa didapatkan oleh para pelaku dengan cara mengirim malware atau virus dengan mengguanakan tautan tersebut. Tetapi jika anda sudah masuk ke halaman yang diminta oleh para pelaku kejahatan, anda harus segera menutup dan mengabaikan agar tidak melanjutkan intruksi selanjutnya.

b. Selanjutnya mengenai modus dari OTP (One-Time Password), ini adalah dengan meminta kode yang terdiri dari sejumlah karakter unik yang diterima oleh Anda untuk bisa mengakses layanan yang lainnya. Karena keberadaannya sangat dirahasiakan, hanya Anda yang dapat mengetahui kode ini, kecuali Anda mengirimkannya ke orang lain jadi kita jangan sembarangan memberitahukan kode OTP kepada orang disekitar kita. Agar terhindar dari para pelaku yang menggunakan modus OTP ini, maka jangan pernah membagikan kode OTP kepada siapapun, baik yang anda kenal ataupun yang tidak anda dikenal. 


\section{SIMPULAN}

Terkait dengan kejahatan cyber crime terhadap tindak pidana pencurian uang nasabah dengan cara pembajakan akun internet banking lewat media sosial menjadi persoalan yang sangat urgent untuk di tindak lanjuti, karena di era modern saat ini, segala kegiatan manusia tidak dapat di pisahkan serta dijauhkan dari Internet serta penggunana akun Internet Banking, dimana segala sesuatunya pada saat ini dituntu untuk menjadi modern akibat perkembangan bidang teknologi dan informasi yang sangat pesat saat ini dan juga merupakan hal yang harus segera diselesaikan. Pemerintah indonesia dalam hal ini merupakan bagian dari Kementerian Informasi dan Komunikasi yang bekerja dengan seluruh stakeholders dan berupaya untuk mewujudkan asa itu.

\section{DAFTAR PUSTAKA}

Buku

Arief, Barda Nawawi, Kajian Mengenai Tindak Pidana Perbuatan Mayantara Terhadap Cyber Crime Di Indonesia, Sinar Grafika, Jakarta, 2015.

-, Penanggulangan Terhadap Tindak Pidana Pada Kejahatan DiBidang Telematika Dan Informatika, Budi Utama, Jakarta, 2010. 2008.

Ramli, Ahmad M. Tinjauan Cyber Law serts terkait dengan Haki, Sinar Grafika, Bandung, 2008.

Suhariyanto, Budi, Tindak Pidana Dari Kejahatan Di Bodang Teknologi Informas, Rajawali Pers Nusantara, Jakarta, 2011.

\section{Internet}

Sumberhttps://nasional.kompas.com/read/2020/10/05/18440581/bareskrim-tangkap-10 tersangka-kasus-dugaanpengambilalihan-rekening-lewat di akses pada tanggal 25 maret 2021 pukul $21.00 \mathrm{Wib}$.

\section{Perundang-Undangan}

Undang - Undang Dasar Negara Republik Indonesia Tahun 1945.

Peraturan Perundang - Undang Nomor 11 Tahun 2008 Mengenai Informatika dan Transaksi Elektronik 